\title{
Severe Iron Deficiency Anemia Due to Late Presentation of Congenital Diaphragmatic Hernia in a Toddler
}

\author{
Oyun Çocuğunda, Geç Bulgu Veren Doğumsal Diyafram \\ Hernisine Băglı A ğır Demir Eksikliği Anemisi
}

\author{
Nazan Sarper ${ }^{1}$, Emine Zengin ${ }^{1}$, Suar Çakı Kılıç ${ }^{1}$, Melih Tugay $^{2}$, Ayşen Aydoğan ${ }^{3}$, \\ Özlem Kayabey ${ }^{1}$
}

${ }^{1}$ Kocaeli University, Pediatric Hematology, Kocaeli, Turkey

${ }^{2}$ Kocaeli University, Pediatric Surgery, Kocaeli, Turkey

${ }^{3}$ Kocaeli University, Pediatric Gastroenterology, Kocaeli, Turkey

\section{To the Editor,}

A 3-year-old female toddler was referred to our pediatric emergency unit with a 2-week history of fatigue, anorexia, progressive pallor, and vomiting. Medical history showed that iron deficiency anemia was diagnosed one year before and oral iron-sulfate was given. She also had a one year history of intermittent vomiting. Her diet seemed adequate in iron-rich foods. Chest X-ray and abdominal ultrasonographic examination performed in a medical center were normal. Complete blood count findings were as follows: $\mathrm{Hb}$ : $1.7 \mathrm{~g} / \mathrm{dL}$; WBC count: $8.0 \times 10^{9} / \mathrm{L}$; ANC: $4.6 \times 10^{9} / \mathrm{L}$; Hct: $6.9 \%$; RBC count: $1.19 \times 10^{12} / \mathrm{L}$; RDW: 20.5; MCV: 58 fL; Plt count: $485 \times 10^{9} / \mathrm{L}$; absolute reticulocyte count: $45.5 \times 10^{9} / \mathrm{L}$ (normal: $50-150 \times 10^{9} / \mathrm{L}$ ). Peripheral blood smear showed hypochromic microcytic red cells, polychromasia, and nucleated red cells. Serum iron was $5 \mu \mathrm{g} / \mathrm{dL}$, total iron binding capacity was $450 \mu \mathrm{g} / \mathrm{dL}$, and ferritin was $<1 \mathrm{ng} / \mathrm{mL}$.

She was hospitalized and given packed red cell transfusion. The following day she suddenly developed respiratory distress after breakfast. Chest X-ray showed a radiolucent lesion in the right paracardiac area (Figure). Congenital diaphragmatic hernia (CDH) was confirmed via barium gastrointestinal X-ray and computed tomography of the chest. During surgery the retrosternal diaphragmatic hernia sack was excised, and the stomach, intestines, and

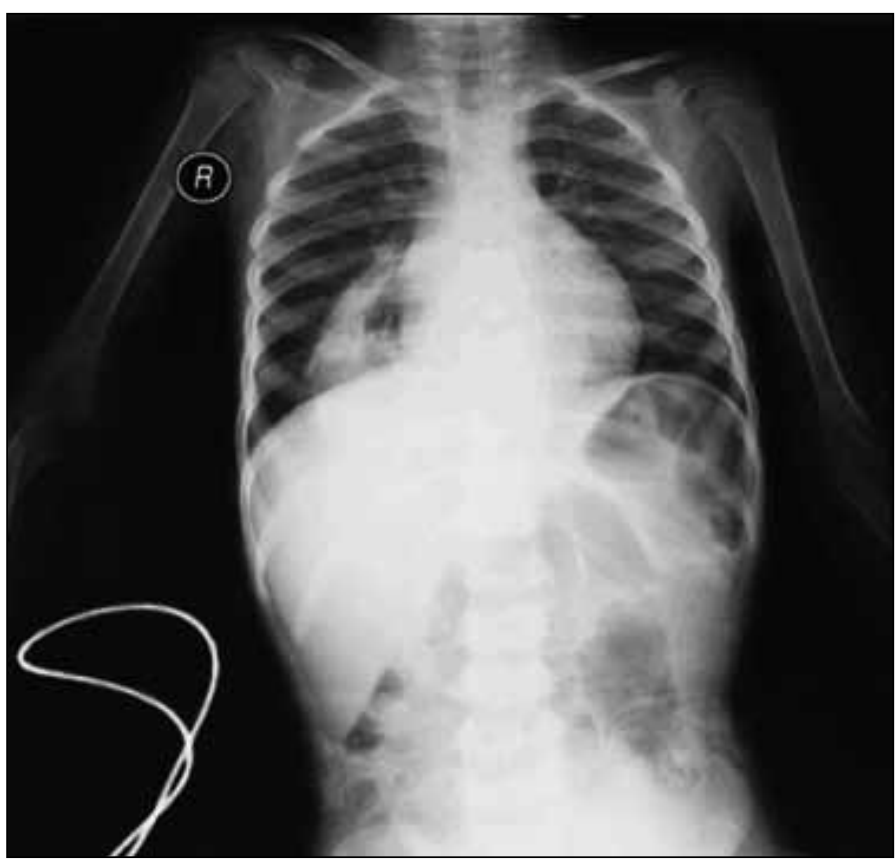

Figure: X-ray of the thorax showing the radiolucent area with clear borders in the right paracardiac region.

\section{Address for Correspondence: Nazan SARPER, M.D.,}

Kocaeli Üniversitesi Tıp Fakültesi Hastanesi Umuttepe Yerleşkesi Kocaeli 41300, Turkey

Phone: +902623037216 E-mail: nazan_sarper@hotmail.com 
transverse colon were reduced to the abdominal cavity. Nissen fundoplication was also performed in an effort to prevent postoperative gastroesophageal reflux; however, another defect was noted on the left posterolateral side of the diaphragm. The defect was repaired and Thal anterior fundoplication was performed. The patient had both Morgagni and Bochdalek defects.

At 6 weeks post surgery the patient had no gastrointestinal symptoms, but her $\mathrm{Hb}$ dropped to $7.9 \mathrm{~g} / \mathrm{dL}$ and fecal occult blood test findings were positive (Hct: $25.6 \%$; RBC count: $3.63 \times 10^{12} / \mathrm{L}$; MCV: 70.5 fL; MCH: 21.9; MCHC: 31; RDW: 24; WBC count: $9.8 \times 10^{9} / \mathrm{L}$; ANC: $4.3 \times 10^{9} / \mathrm{L}$, Plt count: $453 \times 10^{9} / \mathrm{L}$; absolute reticulocyte count: $11 \times$ $10^{9} / \mathrm{L}$ ) [normal $\left.50-150 \times 10^{9} / \mathrm{L}\right]$ ). Peripheral blood smear showed hypochromic microcytic red cells. Esophagogastroduodenoscopy and esophageal biopsy showed erosions, gastroesophageal reflux, chronic inflammation, and hyperplasia of the epithelium. A proton pump inhibitor, domperidone, and anti-acid medications were started. Iron sucrose was administered twice weekly for 3 weeks and the $\mathrm{Hb}$ increased (Hb: $12.2 \mathrm{~g} / \mathrm{dL}$; Htc: $34.6 \%$; RBC count: $4.76 \times 10^{9} / \mathrm{L}$; MCV: 72fL; MCH: 25.6; MCHC: 35.1; RDW: 17.4 ; WBC count: $12.2 \times 10^{9} / \mathrm{L}$; ANC: $8.2 \times 10^{9} / \mathrm{L}$; Plt count: $348 \times 10^{9} / \mathrm{L}$, absolute reticulocyte count: $85 \times$ 10\%/L [normal: $50-150 \times 10^{9} / \mathrm{L}$ ]; ferritin: $16 \mathrm{ng} / \mathrm{mL}$ ). Blood smear showed normal red cells. At the 2-year follow-up the patient had no gastrointestinal symptoms or anemia.

The coexistence of Morgagni and Bochdalek defects is rarely reported [1]. About 5\%-30\% of CDH cases present after the neonatal period, which poses a diagnostic challenge [2]. Such symptoms as vomiting and respiratory distress may be acute or intermittent-sometimes due to gastric volvulus or spontaneous reduction of the hernia to the abdomen. During asymptomatic periods imaging findings may be normal [3]. The presented patient had normal abdominal ultrasound and chest X-ray findings before referral to our department. The presented patient most probably had chronic occult blood loss from the gastrointestinal tract due to reflux esophagitis and mechanical trauma to the diaphragm. Sinaki et al. reported 2 patients-a 19 month-old and 6-year-old-that presented with gastrointestinal symptoms and an $\mathrm{Hb}$ of $5.8 \mathrm{~g} / \mathrm{dL}$ and $6 \mathrm{~g} / \mathrm{dL}$, respectively [4]. Zaki et al. reported a 5-year-old patient with persistent anemia that did not respond to adequate hematinics and blood transfusion. The patient had abdominal pain, melena, an $\mathrm{Hb}$ of $4.8 \mathrm{~g} / \mathrm{dL}$, and multiple linear gastric erosions on the mucosal folds of the lesser curve of the stomach [5].

$\mathrm{CDH}$ must be included in the differential diagnosis of severe iron deficiency anemia in the absence of such obvious causes as nutritional deficiency, melena, hematochezia, and malabsorption. Physicians must be aware that a history of intermittent vomiting and/or sudden onset respiratory distress in young children are indications for imaging of the upper gastrointestinal tract and thorax.

\section{References}

1. Jelin EB, Kim TN, Nathan N, Miniati D. Synchronous ipsilateral Bochdalek and Morgagni diaphragmatic hernias: A case report. J Pediatr Surg 2011;46: 2383-2386.

2. Sridhar AV, Nichani S. Late presenting congenital diaphragmatic hernia. Emerg Med J 2004; 21: 261-262.

3. Davenport M, Holmes K. Current management of congenital diaphragmatic hernia. Br J Hosp Med 1995; 53: 95-101.

4. Sinaki B, Jayabose S, Sandoval C. Iron-deficiency anemia associated with hiatal hernia: Case reports and literature review. Clin Pediatr (Phila) 2010;49: 984-985.

5. Zaki SA, Dadge D, Shanbag P. Diaphragmatic hernia presenting as gastrointestinal bleeding. Indian Pediatr 2010; 47: 185-187. 